Research paper

\title{
To evaluate the anti-kindling effect of allopregnanolone alone and its interaction with sodium valporate in pentylenetetrazole induced kindling model
}

\author{
Puja Kumari ${ }^{a}$, Lekha Saha ${ }^{a, *}$, Neha ${ }^{a}$, Sheekha Vijayanti ${ }^{a}$, Alka Bhatia ${ }^{b}$, \\ Dibyajyoti Banerjee $^{\mathrm{b}}$, Amitava Chakrabarti ${ }^{\mathrm{a}}$ \\ a Department of Pharmacology, Post Graduate Institute of Medical Education E Research (PGIMER), Chandigarh 160012, India \\ ${ }^{\mathrm{b}}$ Department of Experimental Medicine E' Biotechnology, Post Graduate Institute of Medical Education E' Research (PGIMER), Chandigarh 160012, India
}

\section{A R T I C L E I N F O}

\section{Article history:}

Received 18 January 2016

Accepted 4 October 2016

Available online 24 October 2016

\section{Keywords:}

Allopregnanolone

PTZ kindling

Sodium valproate

Combination

Side effects

\begin{abstract}
A B S T R A C T
Background and purpose: Studies in the animal models of epilepsy have suggested the anti-seizure effects of neuroactive steroids and its derivatives in kainic acid and pilocarpine induced limbic seizures and status epilepticus in mice, but no such studies have been reported in the published literature on the role of allopregnanolone in chemical kindling model and its interaction with sodium valproate. The purpose of this study was to evaluate the interaction between sodium valproate and allopregnanolone in pentylenetetrazole induced kindling model in rats.

Methods: In a PTZ kindled Wistar rat model, sodium valproate and allopregnanolone were administered 30 min before the PTZ injection. The PTZ injection was given on alternate day till the animal became fully kindled or till 10 weeks. The parameters measured were latency to develop kindling and incidence of kindling, histopathological study of hippocampus, hippocampal anti-oxidant parameters and hippocampal DNA fragmentation studies.

Results: In this study, the combination of low dose of allopregnanolone with low dose of sodium valproate showed a similar beneficial effect to that of a higher dose of sodium valproate in significantly reducing the number of kindled animals (0/8) as compare to PTZ control group (5/8) as well as the seizure scores and the histopathological scores. The combination significantly reduces oxidative stress by significantly decreasing the MDA levels, and increasing the SOD levels and GSH levels in the hippocampus of rats as compared to PTZ control group. So all these data suggest the antiepileptic effect of the combination and confers the synergistic interaction between the allopregnanolone and sodium valproate.

Conclusions: It can be concluded that by choosing this combination the dose of sodium valproate can be reduced and thereby reduces the incidence of adverse effects caused by sodium valproate and hence proves to be a useful combination clinically. This study has lead the basis to further investigate the various combinations of neurosteroids and valproate in the process of epileptogenesis with better side effect profile.
\end{abstract}

() 2016 Published by Elsevier, a division of RELX India, Pvt. Ltd on behalf of Indian Epilepsy Society.

\section{Introduction}

Epilepsy is a chronic neurological disorder having a prevalence of about $1 \% .{ }^{1}$ It is characterized by the recurrent appearance of spontaneous seizures due to neuronal hyperactivity in the brain. ${ }^{2}$ Epileptogenesis is the transformation of normal neuronal network

\footnotetext{
* Corresponding author.

E-mail address: lekhasaha@rediffmail.com (L. Saha).
}

into an hyperexcitable one. ${ }^{3}$ Some of the underlying mechanism in the initiation and progression of epilepsy after an initial brain insult includes oxidative stress from increased reactive oxygen radicals, apoptosis induction, inflammation, immune modulation and blood brain barrier dysfunction. ${ }^{4,5}$ It is to be noted that despite the increasing availability of newer antiepileptic agents, seizures in one-third patients remains refractory to medical therapy ${ }^{6}$ and epilepsy remains as an ongoing health problem. Among various types of epilepsy, temporal lobe epilepsy (TLE) and drug-resistant type of adult focal epilepsy are the most common. ${ }^{2}$ 
Nuclear factor erythroid-2-related factor 2 (Nrf2) is the primary transcription factor that gets activated in response to oxidative stress and increases the expression of anti-oxidant enzyme such as SOD (superoxide dismutase), catalase, glutathione peroxidase (GSH-Px) and glutathione S-transferase. ${ }^{4}$ Animal models of epilepsy are an important pre-requisite to study the process of epileptogenesis and are used to develop drugs that are antiepileptogenic. Kindling is a chronic model of epilepsy where subconvulsive stimulus (either chemical or electrical), if applied repetitively and intermittently, will ultimately lead to the generation of full-blown convulsions. ${ }^{7}$ It has the advantage of both an epileptogenic and a spontaneous seizure model.

Valproic acid (VPA) is a broad spectrum antiepileptic drug (AED) and are effective against most of the seizure types including primary generalized tonic-clonic seizures, partial seizures, absence seizure, atonic seizures, etc. ${ }^{8}$ But it is associated with adverse effects and the most commonly reported adverse effects of valproate include hepatotoxicity, gastrointestinal disturbances, tremor, body weight gain, platelet disorders and encephalopathy symptoms. ${ }^{9}$ Studies have demonstrated the protective effect of neurosteroids against seizures induced by GABA-A receptor antagonists, including pentylenetetrazole and bicuculline, and are effective against pilocarpine-induced limbic seizures and seizures in kindled animals. ${ }^{10}$ Allopregnanolone ( $3 \alpha$-hydroxy- $5 \alpha$ pregnan-20-one) is a neurosteroids which is the secondary metabolite of progesterone, and has also demonstrated the potent anticonvulsant effects against the secondary generalized component of the amygdale-kindled seizures in rats. ${ }^{11}$

Apart from the anticonvulsant activity, the endogenous neurosteroids play a role in regulating epileptogenesis. ${ }^{12}$ In the kindling model, it was demonstrated that the development and persistence of limbic epileptogenesis are impaired in mice lacking progesterone receptors. ${ }^{13}$ Neurosteroids also play a key role in the pathophysiology of catamenial epilepsy, stress-sensitive seizure conditions, temporal lobe epilepsy, alcohol-withdrawal seizures and in status epilepticus. ${ }^{14}$ So, it can be hypothesized that neurosteroid replacement with natural or synthetic neurosteroids may be useful in the treatment of epilepsy.

Studies in the animals have demonstrated the anti-seizure effects of neurosteroids and its derivatives in kainic acid and pilocarpine induced limbic seizures and status epilepticus in mice. To the best of our knowledge till now no study has been reported in the published literature on the role of allopregnanolone in chemical kindling model and its interaction with sodium valproate. Thus the present study has been contemplated with the aim of establishing the anti-kindling effect of allopregnanolone and its interaction with sodium valproate in chemical kindling model in rats.

\section{Materials and methods}

\subsection{Experimental animals}

All animal procedures and the experimental protocols were approved by the institutional animal ethics committee (IAEC) of the institute before the start of the study. Young male Wistar rats (150-200 g) were used for the present study. The animals were maintained at $23 \pm 2{ }^{\circ} \mathrm{C}$ with a relative humidity of $65 \pm 5 \%$ in $12 \mathrm{~h}$ light/dark cycle. Animals had free access to standard pellet chow diet and tap water ad libitum. Animals were acclimatized to the laboratory conditions for 7 days prior to experimentation.

\subsection{Grouping}

A total of 48 ( $n=8$ in each group) adult male Wistar rats (150$200 \mathrm{~g}$ ) were divided into the following groups: (1) saline control group (0.9\% $\mathrm{NaCl}, \mathrm{w} / \mathrm{v}),(2)$ DMSO control group (0.1\%, w/v), (3) saline + PTZ group (35 mg/kg), (4) sodium valproate $(200 \mathrm{mg} /$ $\mathrm{kg})+$ PTZ group (35 mg/kg), (5) allopregnanolone (0.5 mg/ $\mathrm{kg})+$ PTZ group (35 mg/kg) and (6) allopregnanolone $(0.5 \mathrm{mg} /$ $\mathrm{kg})+$ sodium valproate $(100 \mathrm{mg} / \mathrm{kg})+$ PTZ group $(35 \mathrm{mg} / \mathrm{kg})$; where $\mathrm{NaCl}$ - sodium chloride, PTZ - pentylenetetrazole, DMSO - dimethyl sulphoxide.

\subsection{Drug preparation and dosing scheduled}

PTZ was dissolved in $0.9 \%$ saline and injected intraperitoneally (i.p.) in a volume of not exceeding $10 \mathrm{ml} / \mathrm{kg}$ at a sub convulsive dose of $35 \mathrm{mg} / \mathrm{kg}$. Allopregnanolone $(0.5 \mathrm{mg} / \mathrm{kg})$ was dissolved in a $0.1 \%$ solution of DMSO and was injected subcutaneously (s.c.) $30 \mathrm{~min}$ before PTZ administration. Sodium valproate $(200 \mathrm{mg} / \mathrm{kg}$ ) was dissolved in $0.9 \%$ saline and was administered intraperitoneally 30 min before PTZ injection. All the drugs were given every alternate day until the animal develops kindling or up to 10 weeks. All chemicals used in the present study were in analytical grade and were procured from Sigma Pharmaceutical Industrial Co.

\subsection{Pentylenetetrazole (PTZ) induced kindling in rats}

\subsubsection{Procedure}

PTZ was injected i.p. and after each injection of PTZ, the rat was placed singly in isolated transparent plexiglass cages and was observed for $1 \mathrm{~h}$ and the intensity of convulsions was rated according to the Racine 5-point scale ${ }^{15}$ as follow: 0 - no response; 1 - ear and facial twitching; 2 - myoclonic jerks without rearing; 3 - myoclonic jerks with rearing; 4 - turn over into side position, tonic-clonic seizures; 5 - turn over into back position, generalized tonic-clonic convulsions.

\subsubsection{Endpoints}

An animal was considered kindled, when it exhibits, stage 4 of seizure score on three consecutive trials. Latency to develop kindling in each group, the percentage (\%) of animals being kindled in each group and the percentage (\%) of animals suffering from mortality in each group were recorded.

\subsubsection{Collection of samples}

When the animal became fully kindled (exhibits, stage 4 of seizure score on three consecutive trials), on the next day, it was sacrificed by decapitation under the overdose of anesthetic agent. The hippocampus was carefully dissected out of the brain.

\subsection{Studies with hippocampus}

\subsubsection{Histopathology of hippocampus using hematoxylin and eosin (HEE) strain}

Hippocampus was carefully dissected out of the brain and fixed in $10 \%$ formalin and was subjected to histopathological studies using hematoxylin and eosin (H\&E) stain. A semi quantitative histopathological score was used to determine the relative percentage of damaged neurons as follows ${ }^{16}$ : normal, no injury $=0$; rare neuronal injury $(<5$ clusters $)=1$; occasional neuronal injury $(5-15$ clusters $)=2$; frequent neuronal injury $(>15$ clusters $)=3$; diffuse neuronal injury $=4$.

\subsubsection{Study of oxidative stress parameters in hippocampus}

2.5.2.1. Measurement of thiobarbituric acid - reactive substances. The extent of lipid peroxidation was estimated according to the method of Okhawa et al. (1979). ${ }^{17}$ Tissue homogenate was prepared in a ratio of $1 \mathrm{~g}$ of wet tissue to $9 \mathrm{ml}$ of phosphate buffer (pH 7.2) using a homogenizer. To $0.1 \mathrm{ml}$ of the hippocampal tissue 
homogenate, $0.2 \mathrm{ml}$ of $8.1 \%$ sodium dodecyl sulphate, $1.5 \mathrm{ml}$ of $20 \%$ acetic acid solution, $1.5 \mathrm{ml}$ of $0.8 \%$ aq. solution of TBA was added. The mixture was finally made up to $4.0 \mathrm{ml}$ with distilled water and heated at $95{ }^{\circ} \mathrm{C}$ for $60 \mathrm{~min}$. After cooling with tap water, $1 \mathrm{ml}$ of distilled water and $5 \mathrm{ml}$ of the mixture of normal butanol and pyridine $(15: 1, v / v)$ were added, and the mixture was shaken vigorously. After centrifugation at $4000 \mathrm{rpm}$ for $10 \mathrm{~min}$, the absorbance of the organic layer (upper layer) was measured at $532 \mathrm{~nm}$ in a spectrophotometer against a blank containing the entire reagent accept the homogenate. The MDA equivalents of the sample were calculated using the extinction coefficient $1.56 \times 10^{5} \mathrm{M}^{-1} \mathrm{~cm}^{-1}$.

2.5.2.2. Measurement of superoxide dismutase activity. The activity of superoxide dismutase (SOD) was measured by adopting the method of Kono (1978). ${ }^{18}$ To the test and reference cuvettes, $1.3 \mathrm{ml}$ of solution A, $0.5 \mathrm{ml}$ of solution B and $0.1 \mathrm{ml}$ of solution C were added. The contents were incubated at $37^{\circ} \mathrm{C}$ for $10 \mathrm{~min}$. The reaction was initiated by the addition of $0.1 \mathrm{ml}$ of solution $\mathrm{D}$ to the reaction mixture in test cuvette and the rate of NBT reduction in the absence of enzyme source was recorded. Following this the homogenate was added to the test as well as to the reference cube. Percentage inhibition in the rate of NBT reduction was noted at $560 \mathrm{~nm}$. One unit of enzyme was expressed as inverse of the amount of the homogenate required to inhibit the reduction rate of NBT by $50 \%$. Solution A: $50 \mathrm{mM}$ sodium carbonate solution, $\mathrm{pH}$ 10.0, containing $0.1 \mathrm{mM}$ EDTA; solution $\mathrm{B}$ : $96 \mu \mathrm{M}$ NBT in solution A; solution C: $0.6 \%$ Triton-X-100 in solution A; solution D: $20 \mathrm{mM}$ hydroxylamine hydrochloride in double distilled water, $\mathrm{pH}$ adjusted to 6.0 by $0.1 \mathrm{~N} \mathrm{NaOH}$.

2.5.2.3. Estimation of reduced glutathione. GSH was estimated by the method of Paglia and Valentine (1967). ${ }^{19}$ Hippocampal tissue homogenate was prepared with $0.5 \mathrm{~g}$ of hippocampus with $2.5 \mathrm{ml}$ of $5 \%$ TCA. The precipitated protein was centrifuged at $1000 \mathrm{rpm}$ for $10 \mathrm{~min}$. The supernatant $(0.1 \mathrm{ml})$ was used for the estimation of GSH. $0.9 \mathrm{ml}$ of $0.2 \mathrm{M}$ sodium phosphate buffer ( $\mathrm{pH}-8.0$ ) was added to $0.1 \mathrm{ml}$ of tissue homogenate. Then $2 \mathrm{ml}$ of freshly prepared DTNB solution was added to this and the intensity of yellow color developed was measured in a spectrophotometer at $412 \mathrm{~nm}$ after $10 \mathrm{~min}$. The values of GSH are expressed as $\mu \mathrm{mol} / \mathrm{g}$ sample.

\subsubsection{Hippocampal DNA fragmentation study}

DNA was isolated from hippocampal brain specimens using DNA isolation kits and was subjected to agarose gel electrophoresis to study DNA fragmentation. ${ }^{20}$

\subsection{Statistical analysis}

All the results were expressed as mean \pm standard deviation (SD). Data was analyzed using one-way ANOVA followed by Bonferroni post hoc analysis. $P$-values $<0.05$ were considered as statistically significant.

\section{Results}

\subsection{Effect of various treatments on seizure score in PTZ kindling models}

Rats in both the saline and DMSO control groups showed a seizure score of zero (0) throughout the 10 weeks of the study period. In PTZ (35 mg/kg, i.p.) control group, there was a gradual increase in the seizure score from $3.29 \pm 0.26$ at first week to $3.75 \pm 0.37$ at the end of 10 weeks of study period (Table 1 ). In the PTZ control group, there was progressive increase in the number of kindled animals from $0 / 8(0 \%)$ at 1 st week to $4 / 8$ (50\%) at 5 th week to $5 / 8(62.5 \%)$ at 10 th week (Table 2). Pre-treatment with sodium valproate $(200 \mathrm{mg} / \mathrm{kg}$, i.p.) significantly reduced the seizure score in the PTZ treated animals throughout the 10 weeks of the study period (Table 1). None of the animal developed kindling at any point of time in sodium valproate + PTZ treated group (Table 2 ).

In allopregnanolone $(0.5 \mathrm{mg} / \mathrm{kg}$, s.c. $)$ alone treated group, there was no significant decrease in seizure score as compared to PTZ control group (Table 1). The number of animals developed kindling in allopregnanolone treated group was $2 / 8(25 \%)$ as compared to $5 /$ $8(62.5 \%)$ in PTZ control group (Table 2$)$. The combination group of allopregnanolone $(0.5 \mathrm{mg} / \mathrm{kg}$, s.c.) and sodium valproate $(100 \mathrm{mg} /$ $\mathrm{kg}$, i.p.) showed significant decrease in latency to seizure onset as well as seizure score. The decrease in seizure score was shown over the period of study and was significantly less as compared to that of PTZ control group (Table 1). None of the animal in the combination group developed kindling at the end of the study.

Table 1

Effect of various treatments on seizure score in PTZ kindling model of rats.

\begin{tabular}{|c|c|c|c|c|c|c|}
\hline $\begin{array}{l}\text { Time } \\
\text { (week) }\end{array}$ & $\begin{array}{l}\text { Saline } \\
(0.9 \% \mathrm{NaCl}) \\
\text { control group }\end{array}$ & $\begin{array}{l}\text { Dimethyl } \\
\text { sulphoxide } \\
\text { (DMSO, 0.1\%) } \\
\text { control group }\end{array}$ & $\begin{array}{l}\text { Pentylenetetrazole } \\
\text { (PTZ, } 35 \mathrm{mg} / \mathrm{kg} \text { ) } \\
\text { control group }\end{array}$ & $\begin{array}{l}\text { Sodium valproate } \\
(\mathrm{SV}, 200 \mathrm{mg} / \mathrm{kg})+\mathrm{PTZ} \\
(35 \mathrm{mg} / \mathrm{kg}) \text { group }\end{array}$ & $\begin{array}{l}\text { Allopregnanolone } \\
(0.5 \mathrm{mg} / \mathrm{kg})+\text { PTZ group }\end{array}$ & $\begin{array}{l}\text { Allopregnanolone } \\
(0.5 \mathrm{mg} / \mathrm{kg})+\text { sodium } \\
\text { valproate }(100 \mathrm{mg} / \mathrm{kg})+\text { PTZ } \\
\text { group }(35 \mathrm{mg} / \mathrm{kg})\end{array}$ \\
\hline 1 & $0 \pm 0$ & $0 \pm 0$ & $3.29 \pm 0.26$ & $1.49 \pm 0.47^{@ *}$ & $1.74 \pm 0.15^{\#^{*}}$ & $2.33 \pm 0.39^{*} \$+$ \\
\hline 2 & $0 \pm 0$ & $0 \pm 0$ & $3.24 \pm 0.42$ & $1.79 \pm 0.47^{@ *}$ & $2.56 \pm 0.66^{\#^{*}}$ & $2.16 \pm 0.24^{*}$ \\
\hline 3 & $0 \pm 0$ & $0 \pm 0$ & $2.84 \pm 0.62$ & $1.83 \pm 0.35^{@^{*}}$ & $2.91 \pm 0.58^{\#}$ & $2.83 \pm 0.99^{\$}$ \\
\hline 4 & $0 \pm 0$ & $0 \pm 0$ & $2.83 \pm 0.66$ & $1.74 \pm 0.29^{@ *}$ & $3.37 \pm 0.74^{\#}$ & $2.62 \pm 0.72^{\$}$ \\
\hline 5 & $0 \pm 0$ & $0 \pm 0$ & $3.43 \pm 0.41$ & $2.00 \pm 0.00^{@^{*}}$ & $3.33 \pm 0.77^{\#}$ & $2.38 \pm 0.75^{*+}$ \\
\hline 6 & $0 \pm 0$ & $0 \pm 0$ & $3.03 \pm 0.84$ & $1.91 \pm 0.23^{@ *}$ & $3.25 \pm 0.88^{\#}$ & $2.66 \pm 0.69$ \\
\hline 7 & $0 \pm 0$ & $0 \pm 0$ & $3.50 \pm 0.46$ & $2.12 \pm 0.35^{@^{*}}$ & $3.50 \pm 0.53^{\#}$ & $2.37 \pm 0.69^{*+}$ \\
\hline 8 & $0 \pm 0$ & $0 \pm 0$ & $3.50 \pm 0.46$ & $2.00 \pm 0.00^{@ *}$ & $3.54 \pm 0.50^{\#}$ & $2.37 \pm 0.69^{*+}$ \\
\hline 9 & $0 \pm 0$ & $0 \pm 0$ & $3.50 \pm 0.46$ & $2.00 \pm 0.00^{@^{*}}$ & $3.37 \pm 0.74^{\#}$ & $2.37 \pm 0.69^{*+}$ \\
\hline 10 & $0 \pm 0$ & $0 \pm 0$ & $3.75 \pm 0.37$ & $2.00 \pm 0.00^{@ *}$ & $3.54 \pm 0.50^{\#}$ & $2.37 \pm 0.69^{*+}$ \\
\hline
\end{tabular}

Data are expressed as mean $\pm \mathrm{SD}(n=8)$.

One-way ANOVA followed by Bonferroni post hoc analysis.

@ $P<0.05$ compared to saline control.

\# $P<0.05$ compared to DMSO control.

${ }^{*} P<0.05$ compared to PTZ control.

$\$ P<0.05$ compared to sodium valproate.

$+P<0.05$ compared to allopregnanolone. 
Table 2

Effect of various treatments on induction of kindling by PTZ and total percentage of animals kindled at various point of time.

\begin{tabular}{|c|c|c|c|c|c|c|}
\hline \multirow[t]{2}{*}{$\begin{array}{l}\text { Time } \\
\text { (week) }\end{array}$} & $\begin{array}{l}\text { Saline } \\
(0.9 \% \mathrm{NaCl}) \\
\text { control group }\end{array}$ & $\begin{array}{l}\text { Dimethyl sulphoxide } \\
\text { (DMSO, } 0.1 \% \text { ) Control } \\
\text { group }\end{array}$ & $\begin{array}{l}\text { Pentylenetetrazole } \\
\text { (PTZ, } 35 \mathrm{mg} / \mathrm{kg} \text { ) } \\
\text { control group }\end{array}$ & $\begin{array}{l}\text { Sodium valproate } \\
(\mathrm{SV}, 200 \mathrm{mg} / \mathrm{kg})+\mathrm{PTZ} \\
(35 \mathrm{mg} / \mathrm{kg}) \text { group }\end{array}$ & $\begin{array}{l}\text { Allopregnanolone } \\
(0.5 \mathrm{mg} / \mathrm{kg})+\mathrm{PTZ} \text { group }\end{array}$ & $\begin{array}{l}\text { Allopregnanolone } \\
(0.5 \mathrm{mg} / \mathrm{kg})+\text { sodium } \\
\text { valproate }(100 \mathrm{mg} / \mathrm{kg})+ \\
\text { PTZ group }(35 \mathrm{mg} / \mathrm{kg})\end{array}$ \\
\hline & No. of animals (\%) & No. of animals (\%) & No. of animals (\%) & No. of animals (\%) & No. of animals (\%) & No. of animals (\%) \\
\hline 1 & $0 / 8$ & $0 / 8$ & $0 / 8$ & $0 / 8$ & $0 / 8$ & $0 / 8$ \\
\hline 2 & $0 / 8$ & $0 / 8$ & $0 / 8$ & $0 / 8$ & $0 / 8$ & $0 / 8$ \\
\hline 3 & $0 / 8$ & $0 / 8$ & $0 / 8$ & $0 / 8$ & $1 / 8(12.5 \%)$ & $0 / 8$ \\
\hline 4 & $0 / 8$ & $0 / 8$ & $0 / 8$ & $0 / 8$ & $2 / 8(25 \%)$ & $0 / 8$ \\
\hline 5 & $0 / 8$ & $0 / 8$ & $4 / 8(50 \%)$ & $0 / 8$ & $2 / 8(25 \%)$ & $0 / 8$ \\
\hline 6 & $0 / 8$ & $0 / 8$ & $4 / 8(50 \%)$ & $0 / 8$ & $2 / 8(25 \%)$ & $0 / 8$ \\
\hline 7 & $0 / 8$ & $0 / 8$ & $5 / 8(62.5 \%)$ & $0 / 8$ & $2 / 8(25 \%)$ & $0 / 8$ \\
\hline 8 & $0 / 8$ & $0 / 8$ & $5 / 8(62.5 \%)$ & $0 / 8$ & $2 / 8(25 \%)$ & $0 / 8$ \\
\hline 9 & $0 / 8$ & $0 / 8$ & $5 / 8(62.5 \%)$ & $0 / 8$ & $2 / 8(25 \%)$ & $0 / 8$ \\
\hline 10 & $0 / 8$ & $0 / 8$ & $5 / 8(62.5 \%)$ & $0 / 8^{@ *}$ & $2 / 8(25 \%)^{\#}$ & $0 / 8^{*}$ \\
\hline
\end{tabular}

Data are expressed as mean $\pm \mathrm{SD}(n=8)$, chi-square test.

$@ P<0.05$ compared to saline control.

\# $P<0.05$ compared to DMSO control.

$P<0.05$ compared to PTZ control.

$\$ P<0.05$ compared to sodium valproate.

${ }^{+} P<0.05$ compared to allopregnanolone.

\subsection{Effect of various treatment on degenerative changes and} histopathological score (HPS) of rat hippocampus in PTZ kindling model of rats

A semi quantitative histopathological score was used to determine the relative percentage of damaged neurons. In saline control group the neurons exhibited a normal morphology with intact shape, vesicular nucleus, conspicuous and amphiphilic cytoplasm (overall HS $=0.00 \pm 0.00$ ). In DMSO control group, the neurons exhibited certain changes in hematoxylin and eosin (H\&E) stained sections of rat hippocampus, but overall morphology remain similar to that of the saline control group (overall HS $=0.83 \pm 0.40$ ). On the other hand $\mathrm{H} \& \mathrm{E}$ stained sections from the hippocampus of rat in the PTZ control group showed diffuse neuronal injury with most of the neurons demonstrating nuclear chromatin clumping, hypereosinophilia, condensation of cytoplasm and fragmentation of the cell (overall HS $=3.33 \pm 0.51$ ) (Table 3 and Fig. 1). In contrast the neurons in the sodium valproate $(200 \mathrm{mg} / \mathrm{kg})$ group exhibited near normal physiology similar to that observed in the control group (overall $\mathrm{HS}=1.66 \pm 0.51$ ).

In the allopregnanolone $(0.5 \mathrm{mg} / \mathrm{kg})$ alone treated group, there was decrease in overall HPS (overall HP score $=2.5 \pm 1.04$ ), as compared to PTZ control group (overall HP score $=3.33 \pm 0.51$ ) but it was not statistically significant (Table 3 ). Whereas in the combination group of allopregnanolone $(0.5 \mathrm{mg} / \mathrm{kg}$, s.c.) and sodium valproate
(100 mg/kg, i.p.), most of the neurons exhibited a normal morphology and only few neurons showed features of neurodegeneration (overall HPS $=2.33 \pm 0.51$ ) indicative of occasional neuronal insult (Table 3 ).

\subsection{Effect of various treatments on hippocampal oxidative stress parameters level in PTZ kindling model of rats}

\subsubsection{Effect of various treatments on malondialdehyde (MDA) levels in rat brain}

In the PTZ control group, there was significant increase in hippocampal MDA levels $(627.77 \pm 18.12)$ as compared to saline control group $(291.07 \pm 4.35)$, whereas in sodium valproate $(200 \mathrm{mg} /$ $\mathrm{kg}$, i.p.), allopregnanolone $(0.5 \mathrm{mg} / \mathrm{kg})$ and in the combination of allopregnanolone $(0.5 \mathrm{mg} / \mathrm{kg}$, s.c. $)$ and sodium valproate $(100 \mathrm{mg} / \mathrm{kg}$, i.p.) groups, the hippocampal MDA level was significantly reduced to $405.51 \pm 18.04,546.62 \pm 10.32$ and $474.83 \pm 59.76$ respectively and it was statistically significant when compared to PTZ alone treated groups (Table 4 ).

\subsubsection{Effect of various treatments on SOD levels in rat brain}

The hippocampal SOD level was significantly decreased in PTZ control group $(7.68 \pm 0.62)$ as compared to the saline control $(15.06 \pm 0.86)$ and DMSO control $(14.27 \pm 0.36)$ groups. In the sodium valproate $(13.23 \pm 0.46)$, allopregnanolone $(10.90 \pm 0.63)$, and in the combination of allopregnanolone and sodium valproate

Table 3

Degenerative changes and histopathological score of rat hippocampus in PTZ kindled rats.

\begin{tabular}{|c|c|c|c|c|c|}
\hline Groups & $\begin{array}{l}\text { Cytoplasmic } \\
\text { vacuolation }\end{array}$ & $\begin{array}{l}\text { Nuclear } \\
\text { chromatin } \\
\text { clumping }\end{array}$ & $\begin{array}{l}\text { Hypereosinophilia } \\
\text { and condensed } \\
\text { cytoplasm }\end{array}$ & $\begin{array}{l}\text { Fragmentation } \\
\text { of cells }\end{array}$ & $\begin{array}{l}\text { Histopathological } \\
\text { score }\end{array}$ \\
\hline Saline control group & - & - & - & - & $0.0 \pm 0.0$ \\
\hline DMSO (dimethyl sulphoxide) control (0.1\%) group & - & + & + & - & $0.83 \pm 0.40$ \\
\hline Pentylenetetrazole (PTZ) $(35 \mathrm{mg} / \mathrm{kg})+$ saline group & - & +++ & +++ & - & $3.33 \pm 0.51$ \\
\hline Sodium valproate (SV, $200 \mathrm{mg} / \mathrm{kg})+\mathrm{PTZ}(35 \mathrm{mg} / \mathrm{kg})$ group & - & ++ & ++ & - & $1.66 \pm 0.51^{@ *}$ \\
\hline Allopregnanolone (Allo, $0.5 \mathrm{mg} / \mathrm{kg}$ ) + PTZ group & - & ++ & ++ & - & $2.5 \pm 1.04^{\#}$ \\
\hline $\begin{array}{l}\text { Allopregnanolone (Allo, } 0.5 \mathrm{mg} / \mathrm{kg})+ \text { sodium valproate } \\
(100 \mathrm{mg} / \mathrm{kg})+\text { PTZ }(35 \mathrm{mg} / \mathrm{kg}) \text { group }\end{array}$ & - & ++ & ++ & - & $2.33 \pm 0.51^{*}$ \\
\hline
\end{tabular}

Data are expressed as \% of animals $(n=8)$.

+: mild; ++: moderate; +++: severe; -: absent.

One-way ANOVA followed by Bonferroni post hoc analysis.

@ $P<0.05$ compared to saline control.

\# $P<0.05$ compared to DMSO control.

${ }^{*} P<0.05$ compared to PTZ control.

${ }^{\$} P<0.05$ compared to sodium valproate.

${ }^{+} P<0.05$ compared to allopregnanolone. 
Table 4

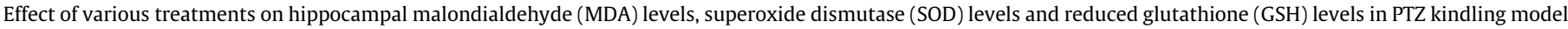
of rats.

\begin{tabular}{|c|c|c|c|}
\hline Groups & $\begin{array}{l}\text { MDA levels } \\
\text { (nmol/mg protein) }\end{array}$ & SOD levels (IU) & $\begin{array}{l}\text { GSH levels } \\
(\mu \mathrm{g} / \mathrm{mg} \text { protein) }\end{array}$ \\
\hline Saline $(0.9 \% \mathrm{NaCl})$ control group & $291.07 \pm 4.35$ & $15.06 \pm 0.86$ & $0.0276 \pm 0.0013$ \\
\hline Dimethyl sulphoxide (DMSO, 0.1\%) control group & $304.57 \pm 7.49$ & $14.27 \pm 0.36$ & $0.0228 \pm 0.0016$ \\
\hline Pentylenetetrazole (PTZ, $35 \mathrm{mg} / \mathrm{kg}$ ) control group & $627.77 \pm 18.12$ & $7.68 \pm 0.62$ & $0.0084 \pm 0.0004$ \\
\hline Sodium valproate $(\mathrm{SV}, 200 \mathrm{mg} / \mathrm{kg})+\mathrm{PTZ}(35 \mathrm{mg} / \mathrm{kg})$ group & $405.51 \pm 18.04^{@ *}$ & $13.23 \pm 0.46^{@ *}$ & $0.0197 \pm 0.0006^{@ *}$ \\
\hline Allopregnanolone (Allo, $0.5 \mathrm{mg} / \mathrm{kg})+\mathrm{PTZ}(35 \mathrm{mg} / \mathrm{kg})$ group & $546.62 \pm 10.32^{\#^{*}}$ & $10.90 \pm 0.63^{\# *}$ & $0.0129 \pm 0.0005^{\# *}$ \\
\hline $\begin{array}{l}\text { Allopregnanolone (Allo, } 0.5 \mathrm{mg} / \mathrm{kg})+ \text { sodium valproate } \\
(100 \mathrm{mg} / \mathrm{kg})+\text { PTZ }(35 \mathrm{mg} / \mathrm{kg}) \text { group }\end{array}$ & $474.83 \pm 59.76^{*} \$+$ & $12.59 \pm 0.91^{*+}$ & $0.0160 \pm 0.0005^{*} \$+$ \\
\hline
\end{tabular}

Data are expressed as mean $\pm \operatorname{SD}(n=8)$

One-way ANOVA followed by Bonferroni post hoc analysis.

@ $P<0.05$ compared to saline control.

\# $P<0.05$ compared to DMSO control.

$P<0.05$ compared to PTZ control.

$\$ P<0.05$ compared to sodium valproate.

$+P<0.05$ compared to allopregnanolone.

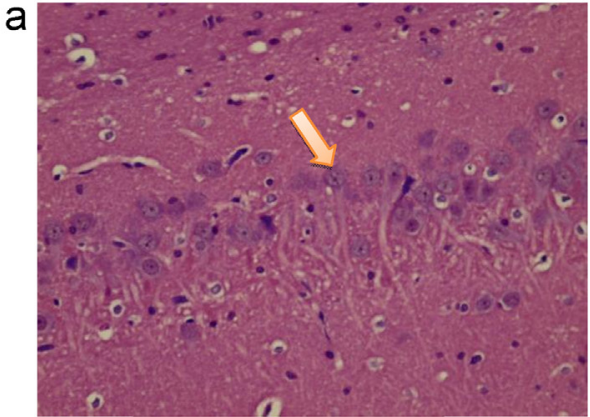

Saline Control Group

C

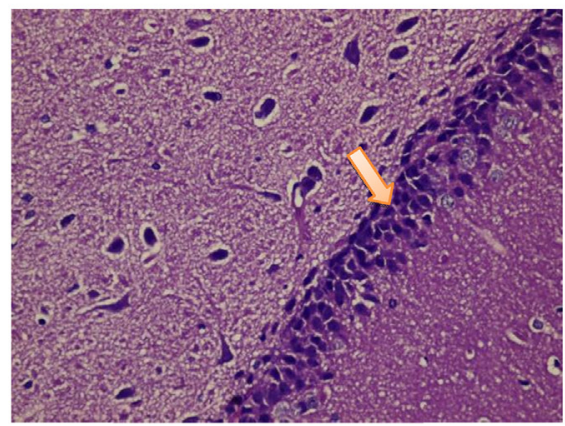

PTZ Control Group

e

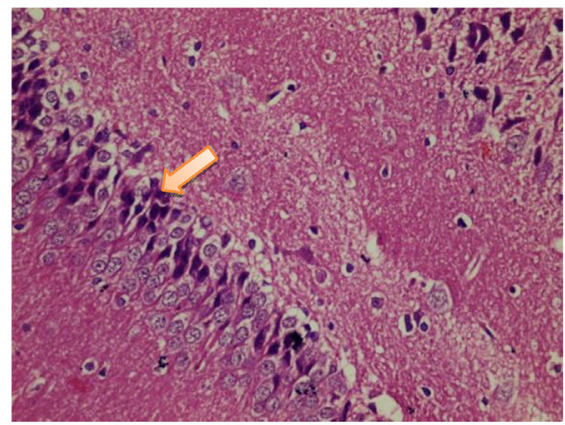

Allo $(0.5 \mathrm{mg} / \mathrm{kg})+$ PTZ group

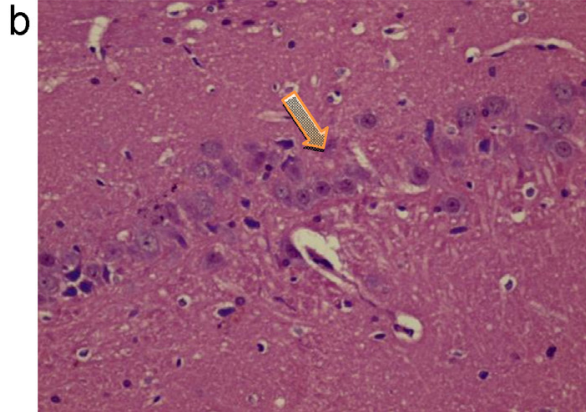

DMSO Control Group

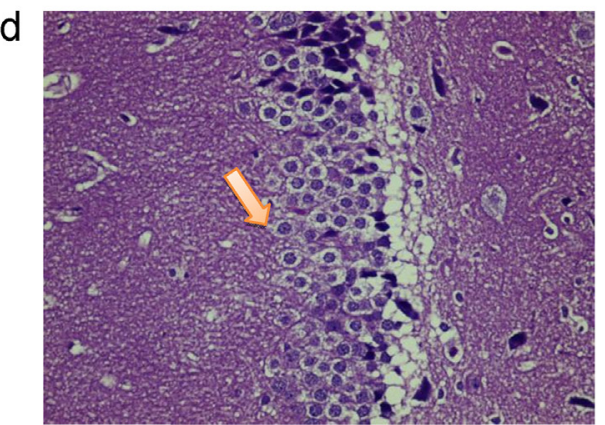

SV $(200 \mathrm{mg} / \mathrm{kg})+$ PTZ group

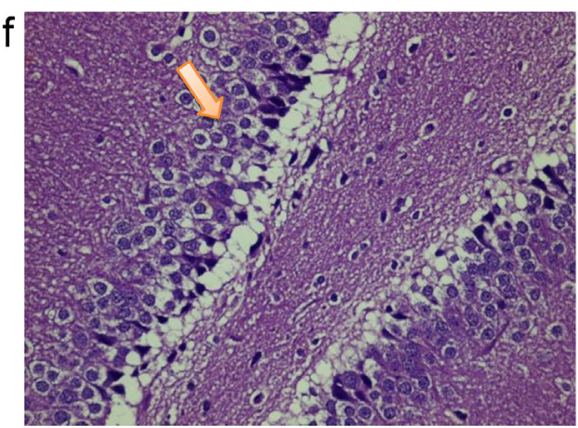

Allo $(0.5 \mathrm{mg} / \mathrm{kg})+\mathrm{SV}$

$(100 \mathrm{mg} / \mathrm{kg})+$ PTZ group

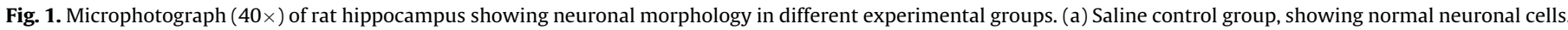

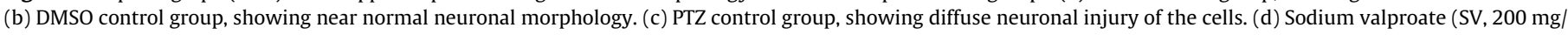

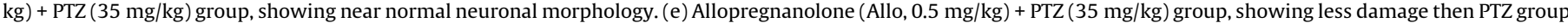

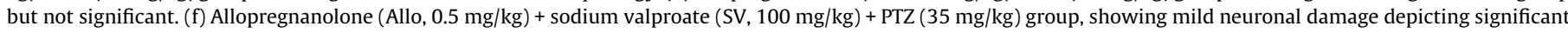
protection. 
$(12.59 \pm 0.91)$ groups, the SOD level in rat's hippocampus were comparable with that of the control group and significantly higher as compared to the PTZ control group of animals (Table 4).

\subsubsection{Effect of various treatments on reduced glutathione (GSH) levels in the rat brain}

In the PTZ control group $(0.0084 \pm 0.0004)$, the GSH level in rat's hippocampus was significantly reduced as compared to the saline control group $(0.0276 \pm 0.0013)$ and DMSO control $(0.0228 \pm 0.0016)$ group. Whereas in the sodium valproate $(0.0197 \pm 0.0006)$, allopregnanolone $(0.1300 \pm 0.0005)$ and in the combination of allopregnanolone and sodium valproate $(0.1600 \pm 0.0005)$ groups, the GSH level in rat's hippocampus were comparable with that of the saline control group and were significantly higher as compared to the PTZ control group of animals (Table 4).

\subsection{Effect of various treatments on the hippocampal DNA fragmentation in PTZ induced kindling model in rats}

The brain samples from different groups were studied for DNA fragmentation. In PTZ control group, DNA fragmentation study showed very prominent smearing in the genomic DNA, which indicates the degradation of genomic DNA and it might be because of chronic seizure, whereas in the sodium valproate $(200 \mathrm{mg} / \mathrm{kg})$ and the saline control group there was no such smearing shown in the genomic DNA. In allopregnanolone $(0.5 \mathrm{mg} / \mathrm{kg})$ alone treated group and in the combination group of allopregnanolone $(0.5 \mathrm{mg} / \mathrm{kg}$, s.c. $)$ and sodium valproate $(100 \mathrm{mg} / \mathrm{kg}$, i.p.), little smearing was observed in the genomic DNA, which might be because of the initial damage to the DNA because of the early development of the oxidative stress due to seizures which affects the bases of DNA (Fig. 2).

\section{Discussion}

The ongoing research in epilepsy aims at developing drugs that prevent the occurrence of epilepsy, improving the adverse effect profile of established drug and decrease oxidative stress in the individuals who are at risk. In this study, the combination of low dose of allopregnanolone with low dose of sodium valproate showed a similar beneficial effect to that of a higher dose of sodium valproate in significantly reducing the number of kindled animals (0/8) as compare to PTZ control group (5/8) as well as the seizure

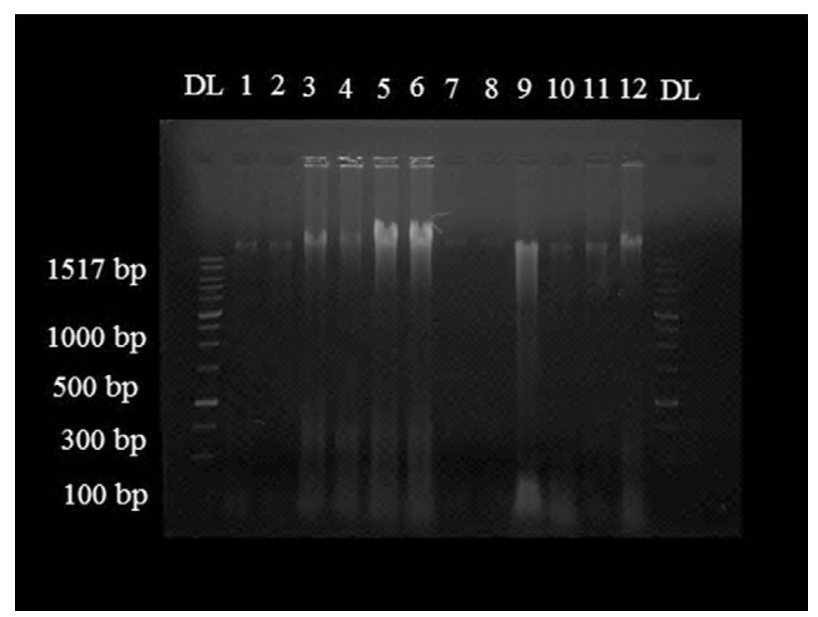

Fig. 2. Effect of various treatments on DNA fragmentation in PTZ treated rats. DL: DNA ladder, 1-2: saline control group, 3-4: DMSO control group, 5-6: PTZ control group, 7-8: sodium valproate (SV, $200 \mathrm{mg} / \mathrm{kg})+$ PTZ (35 mg/kg) group, 9-10: allopregnanolone (Allo, $0.5 \mathrm{mg} / \mathrm{kg})+\mathrm{PTZ} \quad(35 \mathrm{mg} / \mathrm{kg})$ group, 11-12: allopregnanolone (Allo, $0.5 \mathrm{mg} / \mathrm{kg}$ ) + sodium valproate (SV, $100 \mathrm{mg} / \mathrm{kg}$ ) + PTZ (35 mg/kg) group. scores and the histopathological scores. Seizure-induced neuronal loss may occur both acutely, as the result of an initial insult, and chronically, due to subsequent progressive injury. Here PTZ kindled rat showed diffused neuronal injury, whereas sodium valproate $(200 \mathrm{mg} / \mathrm{kg})$ pretreated group exhibited near normal physiology similar to that observed in the control group. In the combination group of allopregnanolone $(0.5 \mathrm{mg} / \mathrm{kg}$, s.c.) and sodium valproate $(100 \mathrm{mg} / \mathrm{kg}$, i.p.), most of the neurons exhibited a normal morphology and only few neurons showed features of neurodegeneration.

The role of oxidative stress and lipid peroxidation in the pathogenesis of seizure has been established. ${ }^{21}$ In the present study, PTZ also produced oxidative stress as there was a significant increase in the brain malondialdehyde levels (indicator of the lipid peroxidation due to free radicals generation) as compared to saline control group. Both sodium valproate and allopregnanolone reversed this increase in brain MDA levels, which was found to be at par with the previous studies, where allopregnenalone showed anti-oxidative properties. ${ }^{22}$

Some antioxidants have been shown to be effective in reducing the oxidative stress in the models of epilepsy. ${ }^{23}$ Normally, biological effects of free radicals in the body is controlled by a lot of antioxidants such as vitamins $\mathrm{A}, \mathrm{C}$ and $\mathrm{E}$, reduced glutathione (GSH) and also via anti-oxidant enzymes like glutathione reductase (GR), glutathione peroxidase (GP), and SOD. ${ }^{24}$ In the present study, the SOD and GSH level was significantly decreased in PTZ control group as compared to the saline control and DMSO control groups. In the sodium valproate, allopregnanolone, and combination of allopregnanolone and sodium valproate groups, the SOD and GSH levels in rat brain were comparable with that of the control group, but were significantly higher as compared to the PTZ control group.

In various published literatures, DNA fragmentation was considered as a parameter showing the apoptosis of brain cells due to the induction of seizures. ${ }^{25}$ The previous studies have shown that when there is apoptosis of the cells, the band observed in agarose gel electrophoresis appeared to be laddered with initial smearing and associated with necrosis. ${ }^{26}$ So, we can say that more smearing and fragmentation means more damage, but for getting a clearer picture of whether smearing was due to apoptosis or necrosis other factors demonstrating apoptosis should be considered. In the present study, the PTZ control group showed very prominent smearing in the genomic DNA. Little smearing was present in allopregnanolone $(0.5 \mathrm{mg} / \mathrm{kg})$ alone group and in the combination group of allopregnanolone $(0.5 \mathrm{mg} / \mathrm{kg}$, s.c.) and sodium valproate $(100 \mathrm{mg} / \mathrm{kg}$, i.p.), which showed protection against the DNA fragmentations.

If we talk about the interaction of sodium valproate and allopregnanolone at the mechanistic level, then we found that both show synergistic interaction as both facilitates GABA signals. Sodium valproate has been shown to increase gamma amino butyric acid (GABA) synthesis in the substantia nigra (SNr). ${ }^{27}$ On the other hand the anticonvulsant effect of allopregnanolone is related to its ability to enhance $\operatorname{GABA}(\mathrm{A})$-mediated $\mathrm{Cl}^{-}$influx, which leads to a decrease in neuronal excitability. Neurosteroids have certain advantages over other anticonvulsant drugs like valproate and benzodiazapines. It has lesser side effect profile which includes mild sedation ${ }^{28}$ and also anticonvulsant tolerance is not seen with neurosteroids in contrast to benzodiazepines. ${ }^{29}$ Also an advantage of hormonally-inactive neurosteroids is that they have no hormonal adverse effects and can be administered throughout the cycle, simplifying the treatment regimen. ${ }^{29}$ Thus, neurosteroids have the potential to be used in the chronic treatment of epilepsy.

To conclude, by a combination of allopregnanolone with valproate, the dose of sodium valproate can be reduced and 
thereby reduce the incidence of adverse effects caused by sodium valproate. However, further studies are required to identify the most effective dose for the combination of allopregnanolone and sodium valproate for a better side effect profile.

\section{Conflicts of interest}

The authors have none to declare.

\section{References}

1. Morimoto K, Fasnestock M, Racine RJ. Kindling and status epilepticus models of epilepsy: rewiring the brain. Prog Neurobiol. 2004;73(1):1-60.

2. Engel Jr J. Introduction to temporal lobe epilepsy. Epilepsy Res. 1996;26(1):141150.

3. Lowenstein DH. Seizures and epilepsy. In: Longo DL, Fauci AS, Kasper DL, Hauser SL Jameson JL, Loscalzo J, eds. In: Harrison's Principles of Internal Medicine 18th edition New York: McGraw-Hill; 2008:2498-2512. [Chapter-369. Section 2: Diseases of the Central Nervous System].

4. Wang W, Wu Y, Zhang G, et al. Activation of Nrf2-ARE signal pathway protects the brain from damage induced by epileptic seizure. Brain Res. 2014;1544:54-61.

5. Liou AKF, Clark RS, Henshall DC, Yin XM, Chen J. To die or not to die for neurons in ischemia, traumatic brain injury and epilepsy: a review on the stress activated signaling pathways and apoptotic pathways. Prog Neurobiol. 2003;69(2):103-142.

6. Kwan P, Brodie MJ. Early identification of refractory epilepsy. $N$ Engl J Med. 2000;342:314-319.

7. Loscher W, Parnham MJ, Bruinvels J, eds. In: Valproate - Milestones in Drug Therapy. Birkhauser; 1999:8. [Table 1].

8. McNamara JO. Pharmacotherapy of the epilepsies. In: Hardman JG, Limbird LE, Molinoff PB, Ruddon RW, eds. In: Goodman E Gilman's The Pharmacological Basis of Therapeutics 12th edition New York: McGraw-Hill; 2011:583-607.

9. Perucca E. Pharmacological and therapeutic properties of valproate: a summary after 35 years of clinical experience. CNS Drugs. 2002;16(10):695-714.

10. Kokate TG, Cohen AL, Karp E, Rogawski MA. Neuroactive steroids protect against pilocarpine and kainic acid-induced limbic seizures and status epilepticus in mice. Neuropharmacology. 1996;35:1049-1056.

11. Lonsdale D, Burnham WM. The anticulvulsant effects of allopregnanolone against amygdala-kindled seizures in female rats. Neurosci Lett. 2007;411(2):147-151.
12. Biagini G, Longo D, Baldelli E, et al. Neurosteroids and epileptogenesis in the pilocarpine model: evidence for a relationship between P450scc induction and length of the latent period. Epilepsia. 2009;50(1):53-58.

13. Reddy DS, Mohan A. Development and persistence of limbic epileptogenesis are impaired in mice lacking progesterone receptors. J Neurosci. 2011;31:650-658.

14. Patil CY, Jadhav SA, Doifode SM, Baig MS. Neuroactive steroids and their role in epilepsy. Int J Basic Clin Pharmacol. 2012;1(3):150-159.

15. Racine RJ. Modification of seizure activity by electrical stimulation. I. Afterdischarge threshold. Electroencephalogr Clin Neurophysiol. 1972;32(3):269-279.

16. Myung RJ, Petko M, Judkins AR, et al. Regional low-flow perfusion improves neurologic outcome compared with deep hypothermic circulatory arrest in neonatal piglets. J Thorac Cardiovasc Surg. 2004;127(4):1051-1057.

17. Ohkawa H, Ohishi N, Yagi K. Assay for lipid peroxides in animal tissues by thiobarbituric acid reaction. Anal Biochem. 1979;95:351-358.

18. Kono Y. Generation of superoxide radical during autoxidation of hydroxylamine and an assay for superoxide dismutase. Arch Biochem Biophys. 1978;186(1):189195.

19. Paglia DE, Velentine WN. Studies on the quantitative and qualitative characterization of erythrocyte glutathione peroxidase. J Lab Clin Med. 1967:7(1):158-169.

20. Sambrook J, Russell DW. Isolation of high-molecular-weight DNA from mammalian cells using proteinase K and phenol. CSH Protoc. 2006;2006(1).

21. Hayashi M. Oxidative stress in developmental brain disorders. Neuropathology. 2009;29:1-8.

22. Kumar A, Goyal R, Prakash A. Possible GABAergic mechanism in the protective effect of allopregnenolone against immobilization stress. Eur J Pharmacol. 2009;602:343-347.

23. Kabuto H, Yokoi I, Ogawa N. Melatonin inhibits iron-induced epileptic discharges in rats by suppressing peroxidation. Epilepsia. 1998;39:237-243.

24. Sudha K, Rao AV, Rao A. Oxidative stress and antioxidants in epilepsy. Clin Chim. 2001;303:19-24.

25. Pollard H, Charriaut-Marlangue C, Cantagrel S, et al. Kainate-induced apoptotic cell death in hippocampal neurons. Neuroscience. 1994;63(1):7-18.

26. Weiss S, Cataltepe O, Cole AJ. Anatomical studies of DNA fragmentation in rat brain after systemic kainate administration. Neuroscience. 1996;74:541-551.

27. Loscher W. Basic pharmacology of valproate: a review after 35 years of clinical use for the treatment of epilepsy. CNS Drugs. 2002;16(10):669-694.

28. Reddy DS, Rogawski MA. Neurosteroid replacement therapy for catamenial epilepsy. Neurotherapeutics. 2009;6:392-401.

29. Reddy DS, Rogawski MA. Chronic treatment with the neuroactive steroid ganaxolone in the rat induces anticonvulsant tolerance to diazepam but not to itself. $J$ Pharmacol Exp Ther. 2000;295:1241-1248. 